Article

\title{
Future of Water Supply and Demand in the Middle Drâa Valley, Morocco, under Climate and Land Use Change
}

\author{
Irene M. Johannsen, Jennifer C. Hengst, Alexander Goll, Britta Höllermann \\ and Bernd Diekkrüger * \\ Department of Geography, University of Bonn, Meckenheimer Allee 166, 53115 Bonn, Germany; \\ irene.johannsen@uni-bonn.de (I.M.J.); j.hengst@uni-bonn.de (J.C.H.); alex.goll@uni-bonn.de (A.G.); \\ bhoellermann@uni-bonn.de (B.H.) \\ * Correspondence: b.diekkrueger@uni-bonn.de; Tel.: +49-228-73-2107 \\ Academic Editor: Sujay Kaushal \\ Received: 3 April 2016; Accepted: 18 July 2016; Published: 25 July 2016
}

\begin{abstract}
Regions of scarce fresh water resources, such as the Middle East and North Africa, are facing great challenges already today, and even more in the future, due to climatic and socioeconomic changes. The Middle Drâa valley in Morocco is one of many semi-arid to arid mountainous areas struggling with increasing water scarcity threatening self-sufficient husbandry. In order to maintain people's livelihoods water management needs to be adapted. The Water Evaluation And Planning System (WEAP) software has been widely used to examine complex water systems in the water resource planning sector all around the world and proved to be a helpful asset to show the various interactions of water supply and demand. This paper presents the application of WEAP on the Middle Draâ valley's water demand and supply, including several socioeconomic and land use scenarios under one basic climate change scenario. The climate scenario shows a significant decrease in available water resources up to 2029 while all socioeconomic scenarios show an increase in water demand. In years of droughts groundwater is used for irrigation, leading to increasingly depleted aquifers. The aquifers are recharged by percolation losses from irrigation and by river bed infiltration the latter of which is stronger in the northern oases than in the southern oases due to water withdrawal rules. A drastic reduction of irrigated agricultural area is the only solution to guarantee sustainable water use.
\end{abstract}

Keywords: IWRM; WEAP model; semi-arid; irrigation; water scarcity; groundwater; reservoir

\section{Introduction}

Today, local water availability depends strongly on demographic changes, the local economy and ecology, and the impact of land use and climatic changes [1,2]. Particularly, regions of scarce water resources, such as the Middle East and North Africa, are currently facing great challenges concerning water scarcity, which are very likely to increase in the future [1]. Agriculture is the mainstay of the African national economy and the majority of the poor works and lives in rural areas and is highly dependent on water availability [3].

Rising average temperatures in addition to less and more irregular precipitation events result in higher water demand for agricultural irrigation [3-6]. Particularly, mountainous regions where altitudinal differences already cause high spatial variability of precipitation and evaporation losses [5,7] struggle with the additional pressure of climatic changes [8-10]. In the mountainous regions of Morocco where the elevation gradient ranges from semi-arid subtropical mountains to arid/hyper-arid pre-Saharan foothills water availability is at risk [6,11-13]. Several studies about current and future water availability in arid and hyper-arid mountainous regions have shown that disparities of water 
supply and water demand are increasing. Concomitance of declining renewable water resources in $[1,5,10]$ and increasing water demand reveals a strong need for water resource management in Northern African arid regions $[6,9,14,15]$.

In order to manage such complex systems that combine hydrological, cultural, and political aspects, effective Integrated Water Resource Management (IWRM) models are needed [15]. The Water Evaluation And Planning System (WEAP) software developed by the Stockholm Environment Institute has shown to be useful for the simulation of possible demand and supply-based changes in water resources systems [16,17]. In the last decade WEAP has been widely used to examine complex water systems in the water resource planning sector all around the world [18-20]. As an example, in several studies of the arid regions of North Africa WEAP revealed connections between vulnerable hydrological systems and social influences and their management concepts [1,14-16,21]. Recently several WEAP models were applied to basins in the arid and mountainous areas of Morocco. WEAP proved to be helpful in showing the various interactions of water supply and demand $[1,5,6,8-10]$.

The aim of this paper is to study the impact of climate change on water availability and water demand on the Middle Drâa valley in Morocco under varying socioeconomic and land use scenarios in order to see how e.g., investments in better irrigation techniques or changes in crop shares may alter water availability in the water system of the Middle Drâa valley. By using socioeconomic and land use scenarios together with climate change scenarios, the study seeks to contribute to an understanding of the system and its possible development and to the development of strategies for a sustainable future of the region.

The present study uses data from the GLOWA IMPETUS-project, with the aim being to analyze the impact of global change on the water cycle in Benin and Morocco. For more details concerning this project refer to [22,23].

\section{Study Area}

The Middle Drâa valley south of the city of Ouarzazate is part of the region Souss-Massa-Drâa in the south east of Morocco comprising an area of about 15,000 $\mathrm{km}^{2}$ (Figure 1) [24]. Climatic conditions are arid to hyper-arid. Rainfall adds up to $200 \mathrm{~mm}$ annually in the north of the basin and $30 \mathrm{~mm}$ in the south, with an average potential evaporation of up to $3000 \mathrm{~mm}$ [11] (Figure 2).

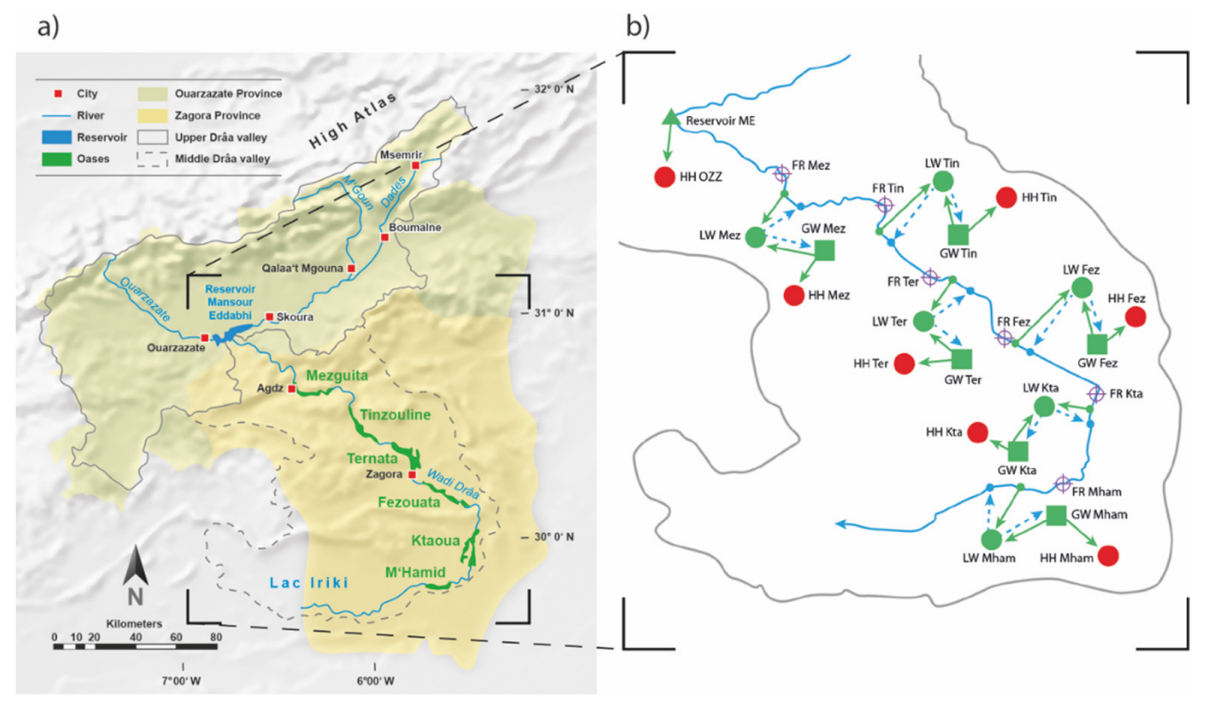

Figure 1. (a) Drâa catchment in an administrative context showing the city of Ouarzazate, the reservoir Mansour Eddahbi and the order of oases along the Wadi Drâa (modified from [24]); (b) WEAP structure as used in this study (GW: groundwater; FR: river network link; HH: domestic water use; LW: agricultural water use; blue arrow: river; green arrow: water transmissions to demand sites; dashed blue arrows: runoff or backflow). 

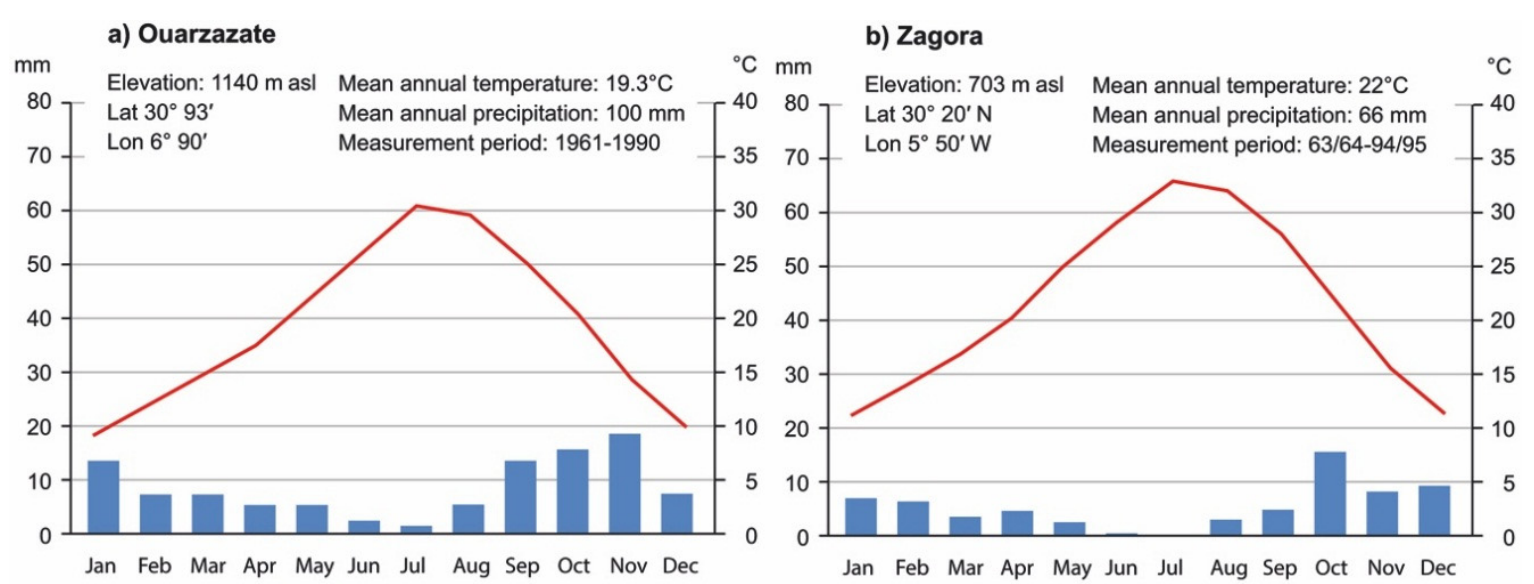

Figure 2. Climate diagram of (a) Ouarzazate showing lower temperatures and higher precipitation than (b) the city Zagora located in the south of the Drâa valley (modified from $[7,24]$ ).

Before 1972 the Wadi Drâa river, which originates from the High Atlas Mountains, ran through the Middle Drâa valley feeding the agriculture of six oases before discharging into the endorheic Lac Iriki [11]. After building the reservoir Mansour Eddahbi surface water distribution of the oases has been managed by periodical reservoir releases, the so-called 'lâchers' in which each oasis receives a specific amount of water [4]. It was thought to open the reservoir seven times a year with a release of 35 million $\mathrm{m}^{3}$ each, based on an estimated annual demand of 250 million $\mathrm{m}^{3}$ for irrigation [24]. Together with evaporation losses from the reservoir of at least 50 million $\mathrm{m}^{3}$ /year, the total water demand for sustainable agricultural use of the Middle Drâa valley sums up to 300 million $\mathrm{m}^{3} /$ year [7]. The actual water releases depend on the reservoir's filling level, which can be less than 100 million $\mathrm{m}^{3}$ per year or may even overstep 600 million $\mathrm{m}^{3}$ [25]. High erosion rates in the semi-arid area have decreased the reservoir's volume from its original capacity of 583 million $\mathrm{m}^{3}$ to 438 million $\mathrm{m}^{3}$ in 1998 [24]. High precipitation variability in the region results in sufficient filling of the reservoir only in 13 of 30 years (1972-2002) [24].

Several crops are cultivated in the oases husbandries, such as wheat, barley, date palms, alfalfa, maize, henna, and some vegetables. Depending on the amount of available water in the reservoir for the coming season and the crop rotation, farmers adapt the extent of cultivated area [26], which fluctuated between $19 \%$ and $100 \%$ in the past (1978-2007). Furthermore, in years of water scarcity, farmers use groundwater for irrigation, which has led to a decline of the groundwater table and a widespread salinization of soils [11,24]. The farmer's livestock comprising cattle, sheep, and goats provide meat for own consumption and, somewhat, for income. Another source for income in the oases is tourism, which comprises safaris into the Sahara and oases scenery [26].

About 280,000 people live in the Middle Drâa catchment, distributed over the six oases and the city Ouarzazate which has about 100,000 inhabitants [27]. Inhabitants of the rural oases are mostly farmers living off self-sufficient husbandry, which does not yield much income. The little income earned due to cash crops, such as henna and dates, are sold at local markets in order to afford fertilizers and fuel for the groundwater pumps [28]. The calculation of income for agriculture is hard to define or evaluate, due to the farmer's prevailing illiteracy and lack of bookkeeping [26]. In comparison to the water consumption of agriculture, the water consumption of the households is much smaller [28]. In the Drâa valley, only about $2 \%$ of the water withdrawal is used for human water consumption.

\section{Methods}

\subsection{WEAP}

WEAP (Water Evaluation And Planning System) is an integrated decision support system that is capable of simulating the water demand and supply for a specific region under parameterized 
assumptions [17]. It combines bio-physical factors influencing the water runoff, such as climate, groundwater hydrology, and land cover with socioeconomic factors such as land use, infrastructure, and water management priorities $[17,20]$. WEAP has been successfully used for the simulation of climate, land use, and population growth changes $[18,19,29]$.

\subsection{Input Data}

The simulations were run on a monthly basis. 1978 was chosen as the current account year which is the starting year in the model. The model consists of six units representing the oases' husbandry and seven demand sites for the city of Ouarzazate and other households within the oases (Figure 1). Irrigation requirements are calculated for seven different crop types. Water is provided by the upstream situated reservoir Mansour Eddahbi and six groundwater bodies situated in the oases. Surface water was defined as the primary source for irrigation demands. The households in the oases receive their water solely from the groundwater bodies, and the city of Ouarzazate exclusively from the reservoir. The model used a historical dataset from 1978-2007. From this baseline all other scenarios were created.

\subsubsection{Hydrologic Parameterization}

Monthly reservoir inflow was provided by [7] for the past period 1978-2007, as well as projection data for the future. Downstream of the reservoir, river bed infiltration and river evaporation values were simulated for each oasis. Groundwater storage is filled by infiltration losses from the Wadi Drâa and by the excess of the irrigation amount.

Annual precipitation data and evapotranspiration for the reservoir were taken from the IMPETUS project and [7]. Potential evapotranspiration for each oasis was calculated using the Hamon equation and a linear relationship based on the gradient in elevation and temperature data from Ouarzazate and Zagora (Figure 2). The relation between elevation difference and evapotranspiration between the two locations was applied to the other oases elevation differences, the result of which was each oasis' specific potential evapotranspiration. The aquifer's properties such as storage capacity, specific yield, and initial storage were taken from [11] (Table 1). The specific yield of the oases varies between $10 \%$ and $22 \%$ (sandy clay to fine sand) and is the only parameter defining the soil's and aquifer's properties.

Table 1. Properties of the six oases aquifers, initial aquifer storages in 1978, the maximum total field size, and the share of each oasis on the water release from the reservoir [11,26].

\begin{tabular}{|c|c|c|c|c|c|}
\hline $\begin{array}{l}\text { Oasis } \\
\text { Name }\end{array}$ & $\begin{array}{l}\text { Aquifer Size/Storage } \\
\text { Capacity (Million } \mathrm{m}^{3} \text { ) }\end{array}$ & $\begin{array}{c}\text { Aquifer's } \\
\text { Specific Yield }\end{array}$ & $\begin{array}{c}\text { Aquifer's Initial Storage } \\
\text { (Million } \mathrm{m}^{3} \text { in the Year } 1978\end{array}$ & $\begin{array}{c}\text { Max. Total } \\
\text { Field Size (ha) }\end{array}$ & $\begin{array}{l}\text { Share on Total Water } \\
\text { Release from Reservoir }\end{array}$ \\
\hline Mezguita & 119 & $19 \%$ & 46.4 & 2419 & $8 \%$ \\
\hline Tinzouline & 254 & $22 \%$ & 74.5 & 4015 & $8 \%$ \\
\hline Ternata & 166 & $15 \%$ & 42.6 & 5858 & $30 \%$ \\
\hline Fezouata & 156 & $10 \%$ & 101.5 & 3825 & $14 \%$ \\
\hline Ktaoua & 5201 & $13 \%$ & 363.8 & 7770 & $28 \%$ \\
\hline M'Hamid & 333 & $15 \%$ & 264.0 & 2231 & $12 \%$ \\
\hline
\end{tabular}

\subsubsection{Reservoir and Households}

The water balance in the study area is strongly influenced by the operation of the Mansour Eddahbi reservoir. For calculating evaporation losses depending on reservoir filling, a volume elevation curve was taken from [7]. A minimum threshold of 35 million $\mathrm{m}^{3}$ was implemented to guarantee drinking water supply for the city of Ouarzazate. On basis of the agricultural water demand and the reservoir's water storage WEAP calculates the required amount of water to satisfy water requirements downstream [17].

Data of the population of Ouarzazate and the oases were obtained from the IMPETUS project. For the future years, census data was extrapolated linearly. The people's mean annual water demand was determined to 50 liters per capita per day in the cities and to 30 liters per capita per day in the oases [11]. 


\subsubsection{Agricultural Area and Irrigation Requirements}

According to the husbandry of the six oases, seven different crop categories were simulated, which were wheat, barley, date palms, alfalfa, maize, vegetables, and henna [26]. Figure 3 shows the crop type area shares for each oasis in 1978. The crop growth parameters (Kc-values) were taken from FAO [30]. Due to technical reasons, date palms were simulated as field of crops although, in practice, the date palms frame the fields.

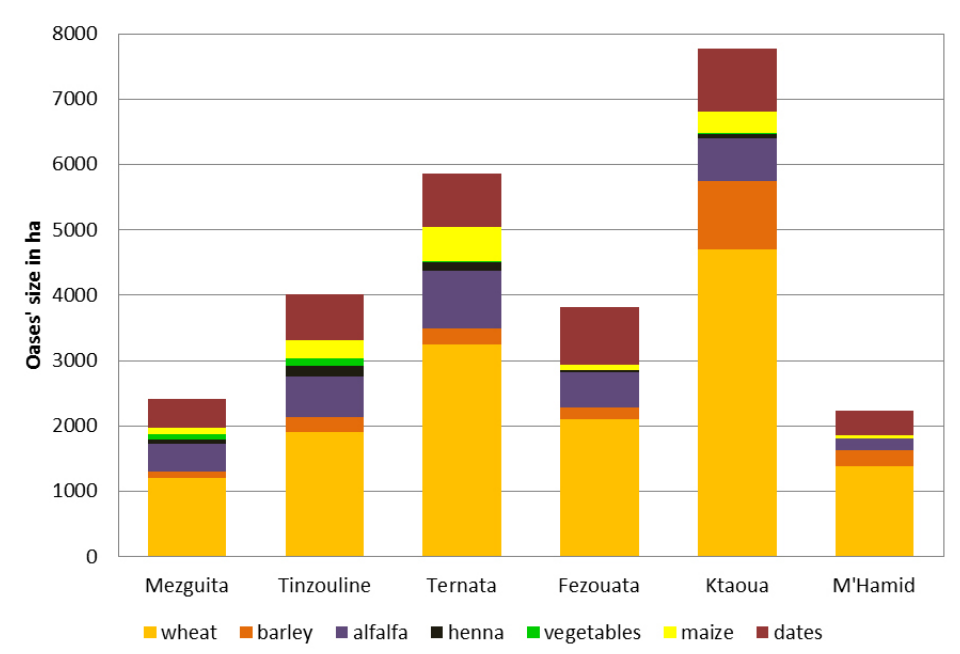

Figure 3. Area used for agriculture in ha per oases and crop type in the current account year 1978 [26].

When reservoir filling is low at the beginning of the growing season, farmers reduce their field sizes as an adaptation method. This strategy was implemented by a factor multiplied to the maximum potential field size with a value between 0 and 1, which is called 'oases factor' in the following. It was taken from the ORMVAO (Organisation de Mise en Valeur Agricole Ouarzazate) for the years 1978-2007 [7,26]. Irrigation efficiency of the agricultural area was specified by WEAP's option of irrigation fraction, which describes the share of water supply being available for evapotranspiration [17]. The irrigation efficiency was set to $85 \%$ representing flood irrigation, and means that only $85 \%$ of irrigation water is available for the crops and $15 \%$ cannot be used by the crops.

The transmission links from the river to the oases and back represents irrigation channels for flood irrigation. In these channels losses to groundwater and evaporation were simulated on the basis of [11]. Flow requirements determine the oases' serial order to receive irrigation water. The last oasis, M'Hamid, gets its water first, followed one after another by the other upstream oases, until the uppermost oasis, Mezguita [26]. This inverse order was implemented by the water authority to guarantee a fair distribution of the water resources over the oases.

\subsection{Future Scenarios}

Based on the current account year 1978 the baseline scenario comprising the years 1979-2007 was constructed. Adapted from the baseline scenario, three main scenarios and two sub-scenarios for the period from 2008 until 2029 were constructed. These scenarios show different socioeconomic changes under the assumption of climate change.

\subsubsection{Climate Scenario}

The impact of climate change on water inflow within the Upper Drâa valley into the reservoir was analyzed by [7]. He applied an adapted version of the SWAT-model which was calibrated and validated for the period 1978-2007 for quantifying the IPCC climate scenarios A1B and B1 up to 2030. He showed that climate change effects for the period 2000-2029 are subject to considerable uncertainties. Nevertheless, a mean decrease in precipitation $(-11 \%)$ and especially snowfall $(-31 \%)$ 
was computed. Busche [7] used two climate scenarios (A1B, B1) and analyzed the uncertainty in future climate related to downscaling methods and ensemble simulations. Since variability in future climate was low, a mean climate scenario was calculated and used as boundary condition in this study. Busche showed that, in the past, in $41 \%$ to $52 \%$ of the years the threshold of $300 \mathrm{Mm}^{3} /$ year [7] was exceeded, this reduces to $27 \%-46 \%$ of the years up to 2030 . For all socioeconomic scenarios the same climate scenario is applied, which shows an increasingly infrequent precipitation and a decreasing precipitation amount, as well as a slow rise in temperature.

\subsubsection{Socioeconomic Scenarios}

The three socioeconomic scenarios developed in the IMPETUS project consider environmental, technological, economic, political, and social changes [31]. In this study the three IMPETUS scenarios were reconstructed and applied (Table 2).

Table 2. Characteristics of the IMPETUS scenarios M1, M2, and M3 (2008-2029) [24,31] (OZZ: city of Ouarzazate).

\begin{tabular}{|c|c|c|c|}
\hline Topic & M1-Marginalization & M2-Rural Development & M3-Business as Usual \\
\hline Population & $\begin{array}{l}\text { OZZ: } 6 \% \text { increase } \\
\text { Oasis: } 6 \% \text { decrease }\end{array}$ & $\begin{array}{l}\text { OZZ: } 3 \% \text { increase } \\
\text { Oasis: constant growth }\end{array}$ & $\begin{array}{l}\text { OZZ: } 4 \% \text { increase } \\
\text { Oasis: } 3 \% \text { decrease }\end{array}$ \\
\hline $\begin{array}{l}\text { Siltation of the } \\
\text { reservoir }\end{array}$ & $\begin{array}{l}\text { Storage volume decrease: } \\
206 \mathrm{Mm}^{3} \text { by } 2029\end{array}$ & $\begin{array}{l}\text { Storage volume decrease: } \\
284 \mathrm{Mm}^{3} \text { by } 2029\end{array}$ & $\begin{array}{l}\text { Storage volume decrease: } \\
214 \mathrm{Mm}^{3} \text { by } 2029\end{array}$ \\
\hline Agriculture area & $\begin{array}{l}\text { Effective cultivated area } \\
\text { do not exceed } 90 \% \text { of the } \\
\text { possible agriculture area }\end{array}$ & $\begin{array}{l}\text { Effective cultivated area does } \\
\text { not fall below } 60 \% \text { of the } \\
\text { possible agriculture area }\end{array}$ & $\begin{array}{l}\text { Effective cultivated area } \\
\text { follows the traditional } \\
\text { climate adaption practices }\end{array}$ \\
\hline Irrigation efficiency & $\begin{array}{l}\text { Decrease of irrigation } \\
\text { efficiency down to } 75 \%\end{array}$ & $\begin{array}{l}\text { Increase of irrigation efficiency } \\
\text { up to } 95 \%\end{array}$ & $\begin{array}{l}\text { Constant value of } 85 \% \text { for } \\
\text { irrigation efficiency }\end{array}$ \\
\hline
\end{tabular}

\subsubsection{M1: Marginalization-Non-Support of the Drâa Region}

Scenario M1 describes a situation of stagnation of the industrial, touristic, and agricultural sector due to the withdrawal of governmental and international institutions. Work migration towards the cities is occurring, although the industrial sector in Ouarzazate is slowly declining. Tourism focuses almost solely on the city of Ouarzazate on a low activity level and does not provide opportunities for economic development. Although, not supported either, subsistence farming is the only choice for many to earn their livelihood. In the oases the agricultural productivity remains constant as a result of no innovations in irrigation and farming techniques. Due to the lack of farming resources, e.g., fertilizers, farmers cannot compete with their cash crops on other regional or world markets. These developments lead to high work migration rates of young people from the oases to cities such as Ouarzazate. As a consequence marginalization is happening in all economic sectors [31,32].

Those changes were generated in WEAP through different parameter adaptations (Table 2): change in population size, sedimentation of the reservoir, the agriculture area, and irrigation efficiency. High migration rates of young people, lead to an increase in population of the city Ouarzazate by $6 \%$, while in the oases population decreases by $6 \%$. The decrease in storage capacity of the reservoir symbolizes the state of non-support, due to the lack of financial grants to delay the erosion processes upstream of the Mansour Eddahbi reservoir. The assumption that no more than $90 \%$ effective cultivated area will be occupied in the model period represents old, inefficient farming techniques and the demographic polarization in the oases of very young and very old inhabitants. Lacking maintenance is constituted by a low irrigation fraction of $75 \%$ due to sedimentation of irrigation channels, which leads to water losses and an increase in evaporation.

\subsubsection{M2: Rural Development through Regional Funds}

M2 in contrast to M1 describes a scenario of social stability, as well as rural and economic development. A positive change can be seen in the city and the oases, due to the improvement of the infrastructure and the job market in tourism. National subsidies and positive effects on global 
markets lead to increases in the agricultural sector. The access to more effective irrigation techniques enables farmers to cultivate larger areas. Livestock farming decreases but still plays an essential role in the oases. Work migration processes slow down due to better living conditions such as educational programs for farmers or the introduction of family planning programs in the rural area [31].

Table 2 shows the parameter changes for the M2 scenario implemented in WEAP. Ouarzazate's population increases by $3 \%$ and remains constant in the oases, because of improving living conditions in the whole area. The decrease in the reservoir's storage volume is slower than in the scenario M1, due to investments in soil protection actions. The assumption for the agriculture area is that at least $60 \%$ is effectively cultivated in the future, due to the improvements in the cultivation processes. The installation of better irrigation techniques leads to an increase in irrigation efficiency to $95 \%$.

\subsubsection{M3: Business as Usual}

The third scenario, business as usual, describes the current socioeconomic trends of the region to remain constant in the future. M3 shows that individual tourism focuses solely on a few selected areas. The population increases, while labor offers stay constant, leading to an increase in work migration. Investments in the agricultural sector are very hesitant. Only the use of motor pumps and fertilizers are common. A small number of farmers profits from rare funding projects by regional organizations [31].

Population growth in the urban area increases by $4 \%$ and reduces by $3 \%$ in the oases. Due to regional investments the storage volume decrease (sedimentation) is slower than in M1, but higher than in M2. The oases factor determining the effective cultivated area was not changed. Regarding the non-investment in irrigation techniques, the irrigation efficiency has a constant value of $85 \%$.

\subsubsection{Sub-Scenarios for the Middle Drâa Region}

The two sub-scenarios L1-Pro dates and L2-Fallow land show hypothetical developments in the study area. The additional scenarios are based on the same parameterization as the main scenarios M1, M2, and M3 but consider changes in the used crops as an adaptation strategy to climatic changes.

\subsubsection{L1-Pro Dates}

In the first sub-scenario, Pro Dates, farmers in the oases increase the amount of date palms and focus on dates as an economic product. Dates are one of two cash crops in the Middle Drâa region [26], which have low production costs because of low demand on nutrients. Henna, the second cash crop, is very water-demanding and cannot compete with cheaper products from e.g., India, and, as such, it is not further considered here. In addition, the households of the oases profit from the tourism effect of date palms, which show the typical scene of an oasis [26]. Fodder crops for livestock are reduced due to a very high water demand [33]. Animals do not only need drinking water, values vary from about 10 liters per day for a goat up to 50 liters per day for cattle [34], but also water for the production of the fodder, which is about 50-100 times the drinking amount [35]. In the Middle Drâa valley sheep, goats, and cattle are the main domestic livestock [26].

In scenario L1 the area for dates increased by 10\%, while the fodder crops barley and alfalfa were reduced to $3 \%$ and $7 \%$ (Table 3 ).

Table 3. Modified agricultural areas for the land use sub-scenarios (2008-2029).

\begin{tabular}{cc}
\hline L1-Pro Dates & L2-Fallow Land \\
\hline Dates increased by $10 \%$ & Barley set to $2 \%$ \\
Barley reduced by 3\% & Alfalfa set to $2 \%$ \\
Alfalfa reduced by $7 \%$ & Henna set to $0 \%$ \\
\hline
\end{tabular}




\subsubsection{L2-Fallow Land}

In the sub-scenario L2 farmers reduce their domestic livestock further to its minimum for the same reasons as illustrated in scenario L1. The area that was formerly used for fodder crop production is now lying fallow in order to save water for essential crops. Due to the high water demand of henna [11] and its low economic value, Henna production was set to zero. Additionally, the cultivated area of barley and alfalfa were reduced to $2 \%$ (Table 3 ).

\section{Results and Discussion}

\subsection{Water Demand}

Figure 4 shows the oases' past water demand and unmet demand from 1978-2007 in relation to the oases factor. It can be seen that the oases' water demand was strongly corresponding to the cultivated area. The oases factor fluctuated between 19\% (1984) and 100\% (1994). Even though field size was reduced significantly, water demand could not be met in the years 1983, 1986, 1995, and from 1999-2005.

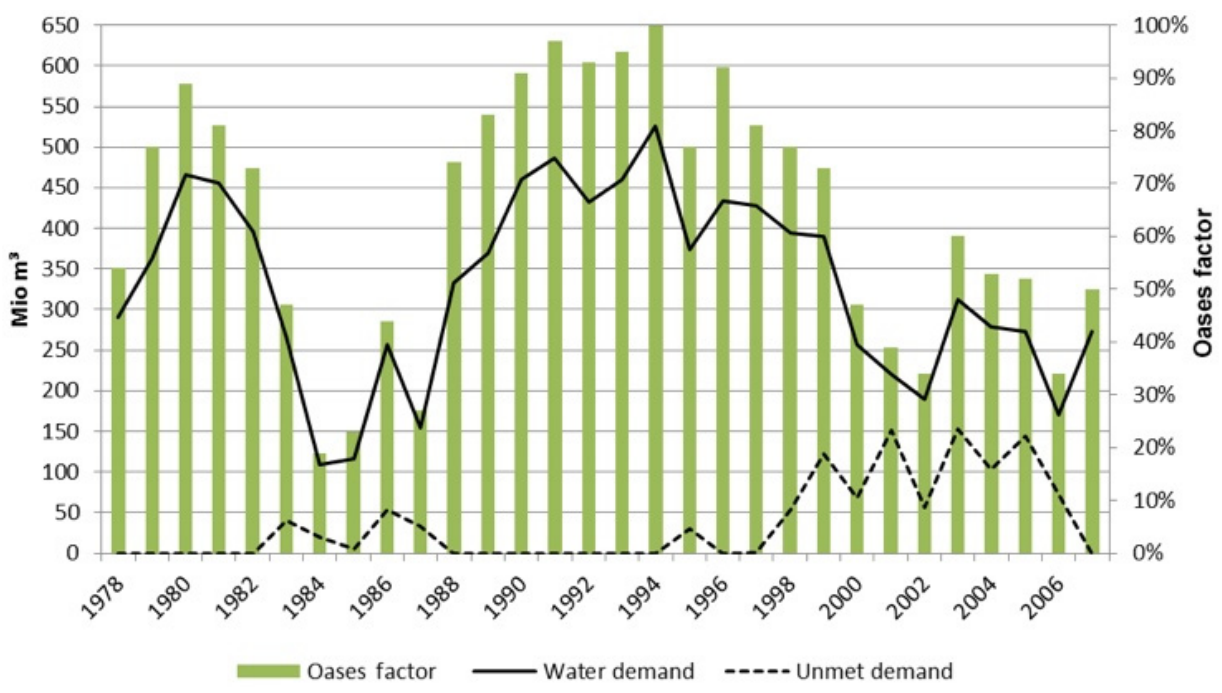

Figure 4. Mean annual water and unmet water demand in the six oases for the period of 1978 to 2007 in relation to the oases factor determining field size. The oases factor shows a strong correlation to the total water demand.

The largest proportion of water demand is required for irrigational purposes for agriculture. Only between $0.08 \%$ (M1), $0.1 \%$ (M2) and $0.09 \%$ (M3) of the water demand is required for domestic use. In general, the water demand of all three scenarios is similar, except of the years 2008 to 2010 and 2026 to 2029 (Figure 5). In those years irrigated area in scenario M1 is enlarged by about 10\% what causes higher irrigation demands. Within years of equal farm size reduction (oases factor) in 2011-2025 water demand of scenario M2 is calculated to be the lowest due to the enhanced irrigation efficiency. Although the farmed area is enlarged in M2 (2008-2010; 2026-2029), the average annual water demand of M1 exceeds M2 by 50 million $\mathrm{m}^{3}$. The growth before 2017 and the reduction of water demand after 2017 is induced by the reduction of field size as a reaction to water scarcity [26]. After 2017 the field size never surmounts $70 \%$, after 2020 it declines further to $60 \%$. The decline to $20 \%$ of field size in 2026 only accounts for scenarios M1 and M3, because the field size of M2 is never allowed to sink below $60 \%$. 


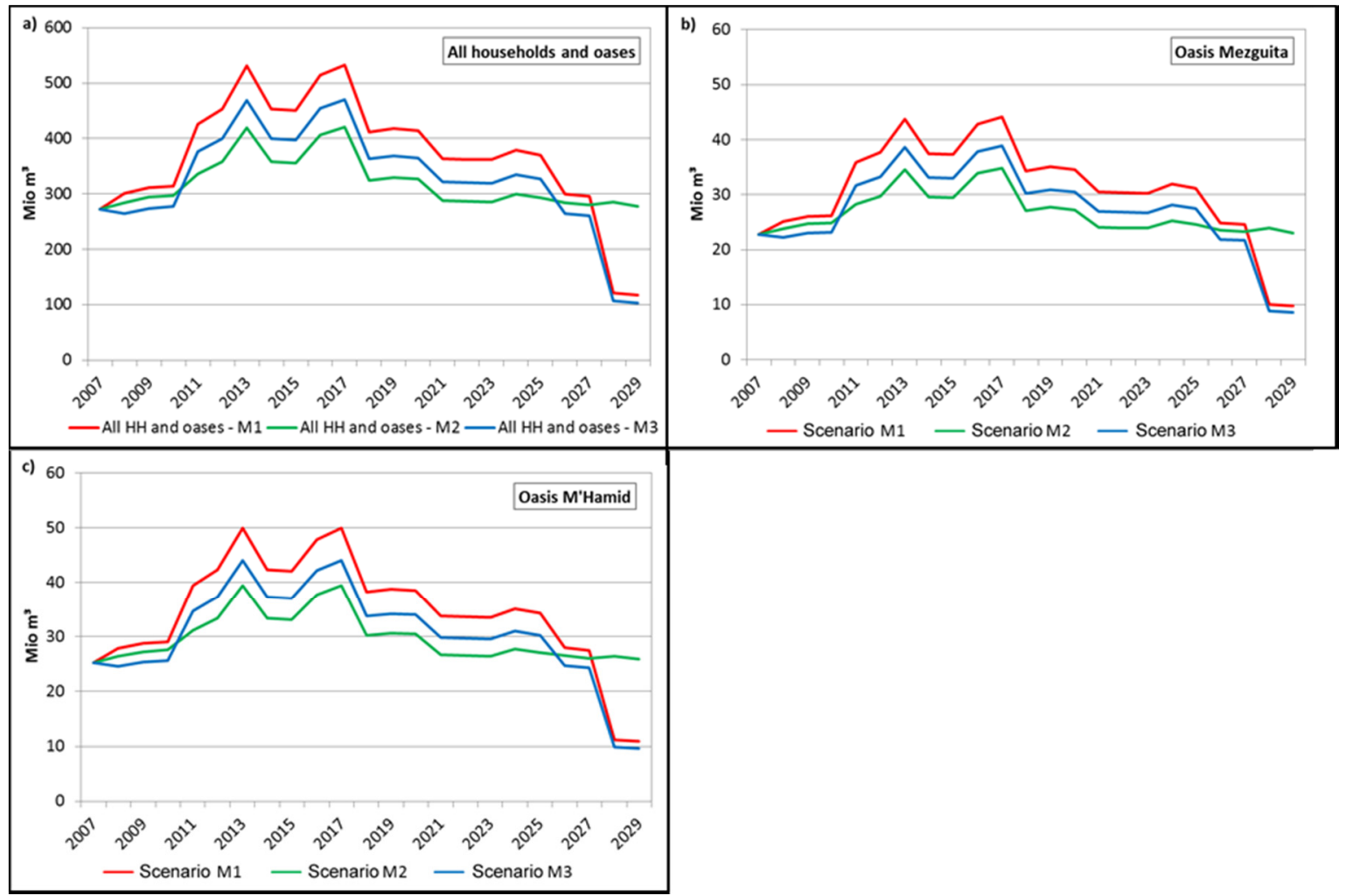

Figure 5. Mean annual water demand in million $\mathrm{m}^{3}$ of the three IMPETUS scenarios M1 (red), M2 (green), and M3 (blue) (2007-2029) for (a) all demand sites; (b) for the oasis Mezguita; and (c) for the oasis M'Hamid. The drastic decrease of water demand in 2028 and 2029 in scenario M1 and M3 is caused by the reduction of the field size due to water scarcity.

Ghallabi et al. [8], who studied groundwater resources in the Moroccan Tensift-Basin, stated that a change in irrigation efficiency by investments in better techniques is not favored by farmers due to the financial risk. It is particularly traditional practices of cultivation area adaptation or the choice of crops that are changed which show large differences in water demand in their scenarios [8].

In the following, the Oasis Mezguita, which is the first one after the reservoir and the Oasis M'Hamid, which is the last oasis at the Wadi Drâa will be discussed for comparison. The two oases are of similar field size and show the biggest difference in evapotranspiration due to the temperature gradient. The aquifer of $\mathrm{M}^{\prime} \mathrm{Hamid}$ has twice the capacity than the aquifer of Mezguita. The difference in water demand between the oases M'Hamid and Mezguita is not caused by the share of crops, but by the difference in ETpot between the most northern and southern oases. The averaged ETpot values (2008-2029) are $2760 \mathrm{~mm} /$ year for the northern oasis Mezguita (SD = $105.9 \mathrm{~mm} /$ year) and $3704 \mathrm{~mm} /$ year for the southern oasis M'Hamid (SD = $106 \mathrm{~mm} /$ year), which makes a difference of about $945 \mathrm{~mm}$ /year. The higher evapotranspiration is the more water is needed for total irrigation, because near to the surface water is evaporating faster and plants transpire more. If temperatures and therefore ETpot is further increasing, agriculture might not be profitable in M'Hamid first, particularly considering that $\mathrm{M}^{\prime}$ Hamid is suffering of increasing salinization problems resulting from the augmented use of groundwater. Salinization as a water quality parameter and its effects on crops cannot be evaluated with WEAP, but has essential consequences on farmers' yields [11].

\subsection{Reservoir}

WEAP's calculations on past annual reservoir water discharge in the time period from 1978 to 2007 averages to 322 million $\mathrm{m}^{3}$ per year (Figure 6). In comparison the predictive years 2008-2029 average annual water outlets between 292 million $\mathrm{m}^{3}$ (M3) and 296 million $\mathrm{m}^{3}$ (M2). The future 
scenarios, thus, predict about 8.1\% (M2) to 9.3\% (M3) less annual reservoir outlet, which comply with all assumptions concerning changing precipitation patterns [13] or the reservoir's sedimentation [24]. Although, the average precipitation is reducing in the future, precipitation stays highly infrequent, also leading to unusual wet years [1,36], such as 2010-2012, which average to an annual reservoir outlet of 840 million $\mathrm{m}^{3}$ (M2) to 878 million $\mathrm{m}^{3}$ (M1).

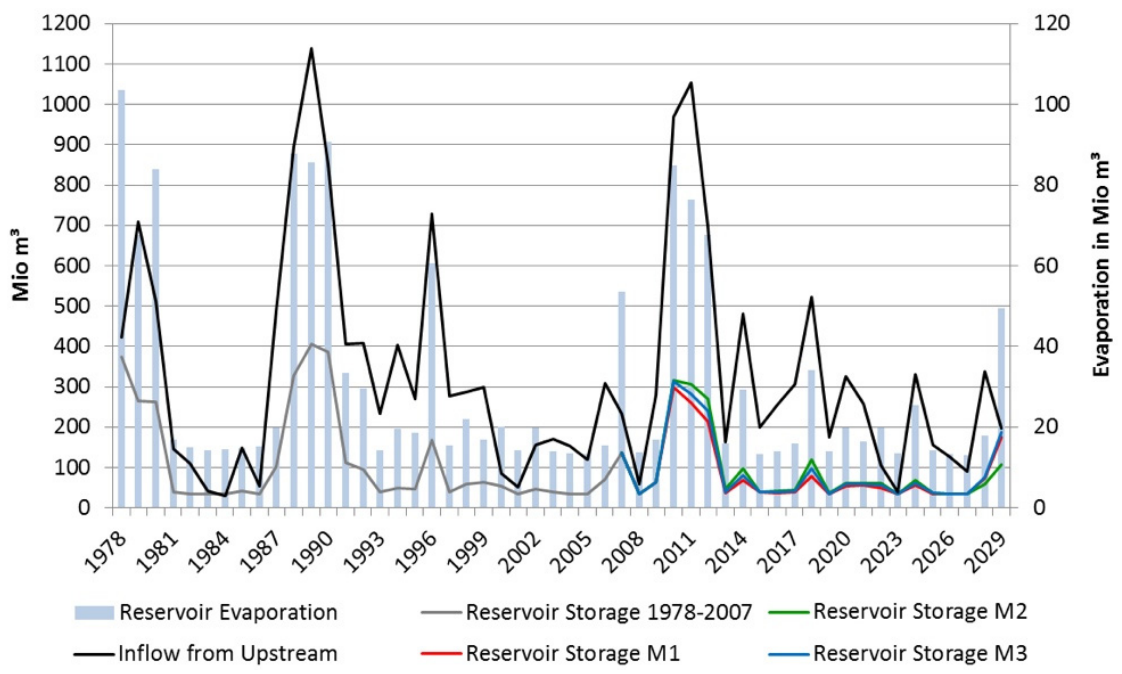

Figure 6. Mansour Eddahbi's reservoir storage in the reference scenario (1978-2007) in gray, continued by the three scenarios M1 (red), M2 (green), and M3 (blue) in million $\mathrm{m}^{3}$ from 2008-2029. The black line shows the reservoir's inflows in million $\mathrm{m}^{3}$ and the blue bars depict the reservoir's net surface evaporation in million $\mathrm{m}^{3} /$ year for the whole time period. The reservoir's inflows show large fluctuations, as does the reservoir's filling level.

Accordingly, the future years up to 2029 show infrequent and smaller recharge events of the reservoir Mansour Eddahbi (Figure 6), which were also found by Karmaoui et al. [6]. These inflows are not sufficient for irrigation of the Middle Drâa valley and to keep an additional surplus in the reservoir, whereas the reservoir's water storage is repeatedly reaching the minimum threshold in all three scenarios.

Within the projected years 2008-2029, the reservoir's actual capacities (1978: 560 million $\mathrm{m}^{3}$ ) are only exceeded from 2010-2012 after years of extremely high inflow (inflow 2009: 281 million $\mathrm{m}^{3} ; 2010$ : 969 million $\mathrm{m}^{3}$ ). In the subsequent years there are only small peaks in the inflow, which cause some annual surpluses in reservoir storage, which are depleted in the next dry year. Altogether, the reservoir is rarely filled to its whole capacity, although Mansour Eddahbi's total storage capacity is constantly

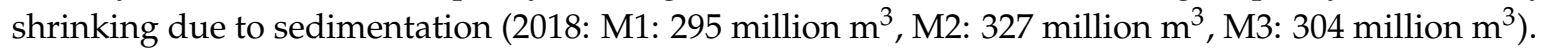

If the water storage does not reach the threshold of 35 million $\mathrm{m}^{3}$, the highest storage capacity is simulated in scenario M2, due to a general lower water demand. This lower water demand is part of the advanced irrigation efficiency (95\%), considering that evapotranspiration is the most influential parameter in semi-arid areas [36]. After 2027 the reservoirs storage of M2 is lower than in the other scenarios, because the agricultural area stays at minimum value of $60 \%$, while the field size of $\mathrm{M} 1$ and M3 reduces to $20 \%$. Accordingly, M2 has a higher water demand and requires more reservoir water after 2027.

All in all, the water resources in the reservoir show a declining trend, which was also found by Droogers et al. within the whole Middle Eastern and North African region [1].

\subsection{Groundwater Storage}

Figure 7a shows drastic groundwater storage fluctuations in all aquifers with a general negative trend. In 2023 all aquifers are exhausted the first time and do not show any permanently improved 
condition afterwards. The aquifers' storage level reflects the filling of the reservoir, because the reservoir's total outlet determines the amount of water infiltrating into the aquifers [11]. The model shows that in years of high inflow into the reservoir (2010-2013) the aquifers in all scenarios are recovering very well (Figure 6). In times of drought, farmers use groundwater to compensate the missing river inflow [37]. Therefore, groundwater in the Middle Drâa oases functions as a buffer when no surface water is available [38]. In the following dry years after 2013 the reservoir cannot release enough water, whereas groundwater is used for irrigation, stressing the aquifers to its limits by 2017 and 2023 at the latest.

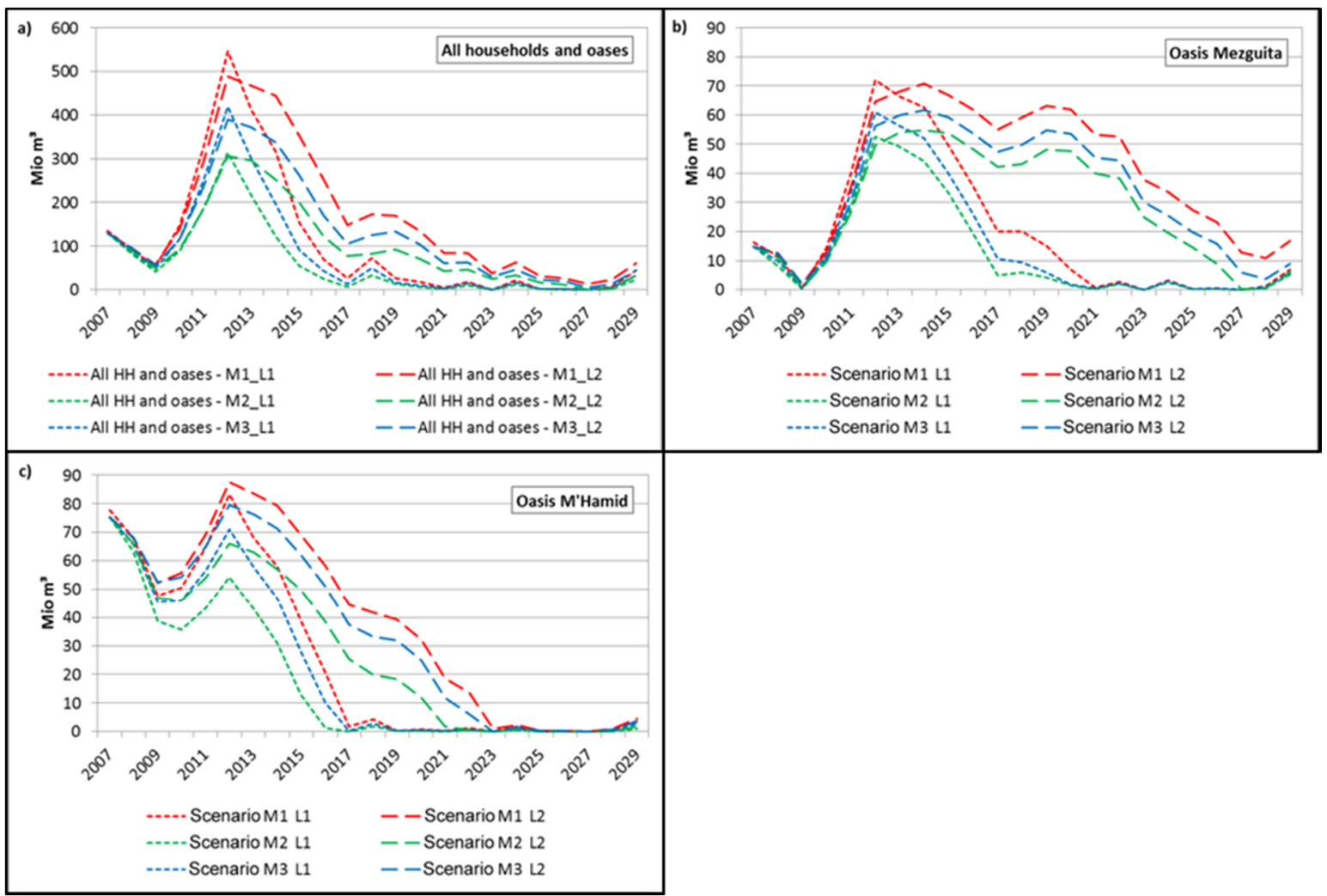

Figure 7. Mean annual groundwater storage in million $\mathrm{m}^{3}$ of the sub-scenarios L1 (small dashed line) and L2 (long dashed line) within the three IMPETUS scenarios M1 (red), M2 (green), and M3 (blue) (2007-2029) for (a) all demand sites; (b) the oasis Mezguita; ans (c) the oasis M'Hamid. The groundwater bodies of L2 are emptied slower than those of L1. The oasis Mezguita shows a strong stability in groundwater table, particularly in scenario L2. After strong recharging events in 2010 and 2011 all aquifers are running empty with time.

Looking at the three scenarios M1, M2, and M3, it is surprising that the aquifer of scenario M2, "rural development", shows the worst conditions. Due to better irrigation efficiency and less water demand, one would expect higher volumes of groundwater storage in scenario M2 compared to M1 and M3. However, because groundwater recharge through precipitation is very low in semi-arid to hyper-arid areas, the aquifer refill relies on indirect infiltration of, e.g., the river bed [11] and on excess of flood irrigation. With improved irrigation techniques, irrigation demand reduces [39]. The part that does not evaporate percolates to the aquifer. Since the irrigation efficiency is $10 \%$ higher in scenario M2 than in scenario M3, less water percolates to the aquifer, resulting in a reduced refilling of the aquifer. The resulting decrease in water demand in M2 leads to less water releases from the reservoir, reducing the amount of water free for percolation. Summing up, the aquifer storage is declining when flood irrigation is replaced by more efficient irrigation techniques and less irrigation water demand. The saving of reservoir water by the new techniques in M2 is still not enough to satisfy the crops' 
water demand. Still, additional groundwater has to be used. The saving of water by new irrigation methods must be efficient enough to save sufficient reservoir water to satisfy irrigational purposes in 'regular dry' years. The aim should be to use groundwater only in very dry years in order to give the aquifers time to recover and to provide a buffer in years of need. To reach this stable and sufficient state, the supply-demand imbalance must be overcome. Since no additional water can be provided, the water needed must be reduced [14], either by installing better irrigation techniques or by reducing field size. The surplus in reservoir water in scenario M2, however, is not sufficient in order to relieve groundwater bodies in a regular dry season. As a result, the lower water demand of scenario M2 caused by better irrigation efficiency cannot counterbalance the lack of aquifer recharge when groundwater is used for irrigation.

Looking at the aquifer conditions of Mezguita and M'Hamid (Figure 7b,c), the two aquifers show different developments. Mezguita's groundwater table is depleted much slower in comparison to M'Hamid's. There are two reasons for this. First, the general temperature gradient from the north to south of the Middle Drâa valley generates a higher potential evapotranspiration in the south than in the north. Hence, water applied to the fields by flood irrigation in M'Hamid evaporates faster and is not available for groundwater recharge. Second, Mezguita's location as the first oasis downstream of the reservoir leads to extended riverbed infiltration. Although Mezguita receives surface water for irrigation latest, due to distribution rules, water is running through the riverbed for a longer period compared to the other oases. Hence, riverbed infiltration is recharging the aquifer throughout the whole time when the reservoir is open. This effect loses strength with the subsequent order of oases downstream. M'Hamid's aquifer, which is the oasis last in line, recharges only about 20 to 30 million $\mathrm{m}^{3}$, while Mezguita's aquifer recharges about 50 to 70 million $\mathrm{m}^{3}$ in the years of high water supply from 2009-2012. This lack of recharge is also the reason why M'Hamid's groundwater body is empty in 2017 before Mezguita's in 2021.

Although, M'Hamid is the last oasis in line with less riverbed infiltration it shows very high initial groundwater storage in 2008. The aquifer's initial good condition in 2008 can be explained by the relation of the M'Hamids' very small cultivated field size to the large aquifer capacity of $333 \mathrm{million}^{3}$ (Table 1). Surface water is mostly capable of satisfying the oasis' water demand, however, if not, M'Hamid's aquifer is able to buffer for a long period of time.

Groundwater Storage in the Land Use Scenarios

Years of drought and recovery show different dimensions in the two land use scenarios L1 and L2 (Figure 7). Due to the high water demand of date palm trees, groundwater bodies are utilized stronger in scenario L1. For L1 groundwater bodies are nearly emptied by 2016-2017 while, in the fallow land scenario L2, the aquifers are emptied by 2027 because L2 needs less water. For that reason, exploitation happens slower and recharge events have more effect on the aquifers in L2.

No matter what scenario is chosen, within 20 years the aquifers will be empty. For that reason, none of the scenarios show sustainable water management solutions. The reduction of field size is the key factor for a sustainable solution that may spare the aquifers. Other variables, such as irrigation efficiency and crop type, significantly influence water demand, but are less likely to be considered by farmers [8]. The conditions and depletion of aquifers in the Middle Drâa valley are not a single case in Morocco. Messouli et al. state that groundwater storages are strongly affected by human overexploitation due to uncontrolled groundwater use [5].

\subsection{Unmet Demand}

For all three scenarios water release from the reservoir in 2010 until 2014 is sufficient to feed the needs of all farms in the Middle Drâa valley (Figure 8). Afterwards, the reservoir's storage drops within a year because storage capacity is not enough to compensate for longer droughts. From 2012 to 2014 , the filled up groundwater reserves are capable to buffer parts of the lacking surface water in all oases. The farmer's choice of enlarging cultivated field sizes lead to a growing unmet demand from 
2015 on. The reduction of field size and large precipitation events in the High Atlas Mountains, which refill the reservoir and groundwater storages reduce the unmet demand in 2018. Afterwards, field size is constant causing an increase in unmet demand because reservoir and groundwater resources are depleted (Figure 6). In the year 2023 the maximum unmet demand of 362 million $\mathrm{m}^{3}$ (M1) is simulated caused by an extreme low inflow into the reservoir. In this year groundwater storages and the reservoir storage are empty. After a significant reduction in field size and a refill of aquifers and reservoir, the unmet demand reduces to zero in 2028-2029. The unmet demand. hence, reflects the interactions between groundwater and reservoir storage, as well as the cultivated field size (under the assumption of the same share of crops grown).

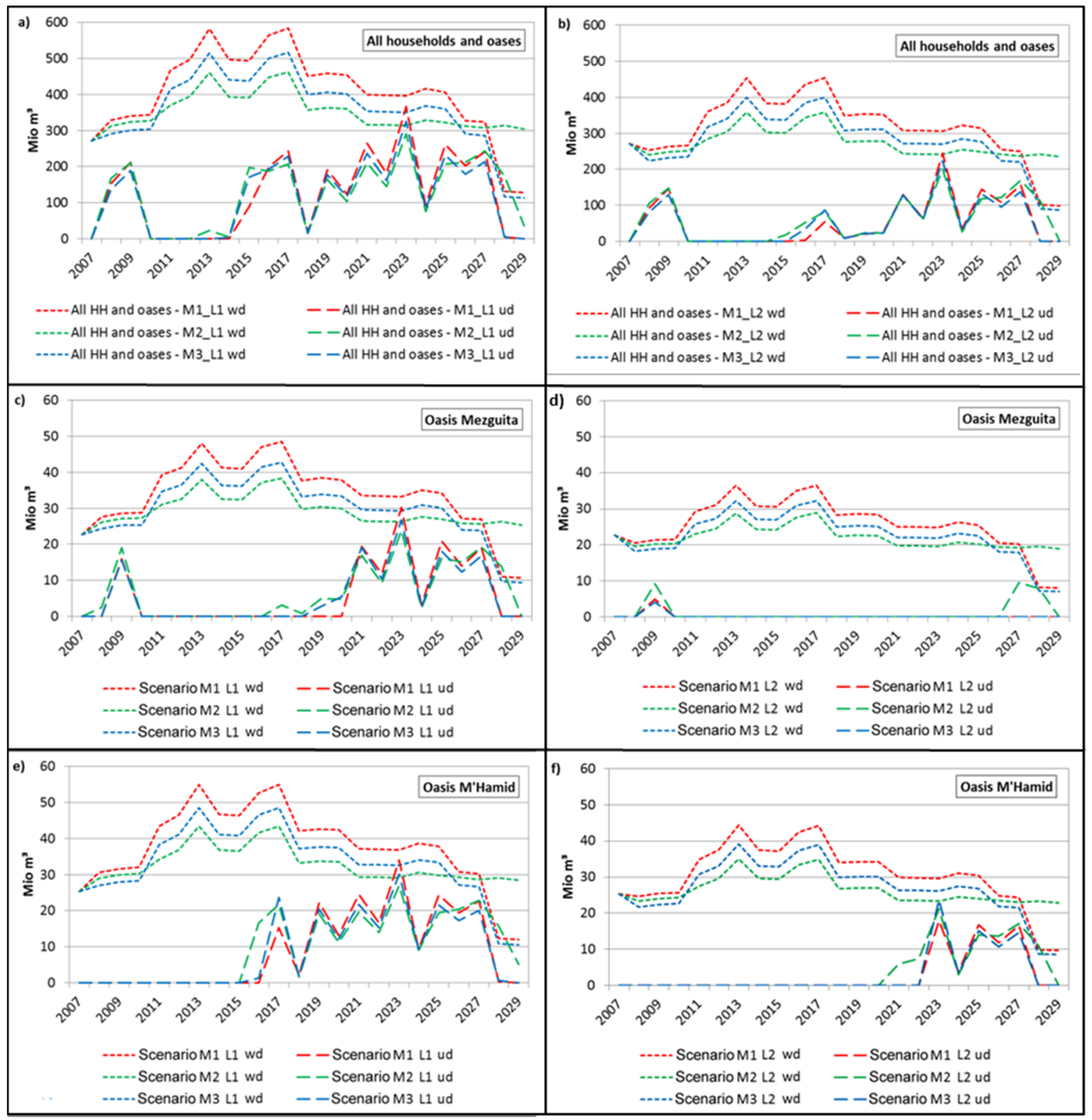

Figure 8. Mean annual water demand (wd, small dashed lines) and unmet demand (ud, long dashed lines) in million $\mathrm{m}^{3}(\mathbf{a}, \mathbf{b})$ of the three scenarios M1 (red), M2 (green), and M3 (blue) (2007-2029) under the sub-scenarios L1 and L2; (c,d) of the oasis Mezguita; $(\mathbf{e}, \mathbf{f})$ of the oasis M'Hamid. Water demand and unmet demand show less magnitude in the sub-scenario L2. 
Scenario M2 shows most of the time the lowest unmet demand, but excels with respect to the other scenario's unmet demands in the years of extended farm sizes. When comparing the ratio between unmet demand and water demand of each scenario M2 shows 31\% of water demand being unmet, M1: $26 \%$, and M3: $28 \%$. These results are surprising, considering the water demand of M2 to be much smaller than of scenario M1 or M3. The higher water demand of scenario M1 and M3 are buffered by the aquifers, which show higher storage levels due to differences in the scenario's irrigation efficiencies. Due to less fillings in the reservoir in scenario M1 and M3, groundwater has to buffer agriculture's water demand. This causes the higher groundwater levels of scenario M1 and M3 to approximate to those of M2 by 2023.

At the scale of a single oasis the unmet demand mirrors the depletion of the aquifer. Mezguita shows a peak of unmet demand due to its depleted aquifer in 2009 (Figure 8b), while the aquifer of M'Hamid buffers the lack of surface water in the same year (Figure 8c). The more the aquifers are depleted, the higher is the unmet demand, until the aquifers are empty and only surface water is the remaining source for irrigation. In general, unmet demand of $\mathrm{M}^{\prime} \mathrm{Hamid}$ is higher due to its southernmost location, which is prone to higher evapotranspiration losses and less refilling by riverbed infiltration.

It must be considered that WEAP's groundwater budgeting lacks accuracy and is, thus, bonded with high uncertainties. Important parameters for groundwater infiltration as e.g., aquifer characteristics, aquifer interactions, or mixed soil properties cannot be taken into consideration. For a certain quantitative analysis of the aquifer's volume, another model, e.g., MODFLOW, should be linked to WEAP. The simulated trends showed that subsidies for better irrigation techniques would help reducing water demand in future.

\subsubsection{Water Demand and Unmet Demand in the Land Use Scenarios}

The change in crops in the land use scenarios result in changed water demands (Figure 8). Date palms need more water than barley or alfalfa, which is why the water demand in scenario L1 is generally higher than for the other scenarios. Accordingly, unmet demand rises. Fallow land in scenario L2 reduces irrigated area, which lowers water demand (Figure 8d-f). Thus, scenario L2 always has less water demand and less unmet demand than all other scenarios.

Mezguita shows a surprisingly small unmet demand through all land use scenarios (Figure 8b,e), here exemplarily shown for L2-M3 (Figure 8e). This is due to the aquifer of Mezguita, which maintains stable for a long time due to riverbed infiltration. Together with the reduction in field size in scenario L2, the aquifer of Mezguita stays filled until 2027. The development of the aquifer of $\mathrm{M}^{\prime}$ Hamid in scenario L1 does not show much difference between the three scenarios (Figure 8c) although the aquifer is filled much longer in scenario L2. Still, scenario L2 is not a sustainable solution for this oasis.

When reducing field size, it must be considered that husbandry in the Middle Drâa valley oases is for self-supply [26]. To assess future water demand and supply for the Middle Drâa valley, it needs to be analyzed how much yield is necessary to guarantee a satisfying lifestyle for the farmers. Already, today, farmers reduce fodder production when water is scarce [26].

When growing cash crops as modeled in scenario L1, farmers would be able to buy meat or food in times of severe droughts. A safe income would give farmers independence from dry years and remittances. A survey conducted by Storm [40] revealed that in the oasis Ternata 33\% of farmers already receive remittances from their sons, which they need in order to buy diesel for the groundwater pumps or fertilizers. Date palms have a high water demand, which results in a lower unmet demand for land use scenario L2 than for land use scenario L1. However, date palms tolerate soil and water salinity [41], which are basic prerequisites for future crops in the Middle Drâa valley's agriculture [11].

In this paper only water quantities are taken into account. Another important factor for crop yields, though, is water quality. As mentioned before, the Drâa region suffers of growing salinization due to groundwater irrigation. Since salinity is observed to increase and aggravated the situation 
of water demand, particularly in the southern oases, further research should concentrate on the salinization of aquifers, e.g., using the FAO AquaCrop model.

\section{Conclusions}

Self-sufficient crop farming in the future of the Middle Drâa valley will be highly endangered by water scarcity under global change conditions. The WEAP model of the water resources in the Middle Drâa valley showed the inhabitant's high dependency on surface water from the high Atlas Mountains which might increasingly become unreliable due to climate change impacts. Additionally, it was shown that compensatory water taken from the oases' aquifers is only a temporary and non-sustainable solution, because recharge events are not sufficient to keep the groundwater table stable.

The gained insights into the Middle Drâa valley's future water demand and supply show that the way farming is performed today in the oases of the Middle Drâa valley will not work out in future and, therefore, needs management solutions in order to preserve water and food resources [5,6,10,37,42].

The management solutions looked at in this paper are better irrigation techniques, the prevention of the reservoir siltation, the adaptation of field size, and the choice of crops. Enhanced irrigation leads to less water infiltration to the aquifers, but lessens the overall water demand of surface water. Through the prevention of reservoir siltation, more water can be stored in case of high precipitation events, such as simulated in the years 2010-2012. Adaptation of field size showed the strongest impact on water demand reduction, but lessens the outcome of already sparse yields. The choice of crops also has an impact on water demand, but decreases crop variety and fodder crops for livestock. Further research should focus on the question if the profit out of increased date palm cultivation is sufficient to guarantee the farmer's livelihood.

The two land use scenarios showed the influence of crop types grown and field size reduction. Both possibilities of coping with water scarcity showed no satisfying results. The reduction of fodder plants reduces agriculture's water demand significantly so that aquifers stay stable longer, but still show a decreasing trend. When focusing on the production of cash crops, water demand rose even higher. Further research might show how much food farmers could buy for the benefits of dates and if this exchange might balance the water they have to use for own food crops. In this case field size of food crops would reduce further and lead to less water demand.

Altogether, the system shows a decrease in water resources and all presented scenarios showed no way to handle these for a sustainable agriculture in the six oases of the Middle Drâa valley. If nothing is done by the stakeholders, self-sufficient husbandry will not be possible in the close future.

Acknowledgments: We would like to thank Anna and Stephan Klose, Henning Busche, Claudia Heidecke, the FAO, and the IMPETUS project for providing us with data. We are thankful to the ORMVAO (Organisation de Mise en Valeur Agricole Ouarzazate) for providing data on water resources and oases.

Author Contributions: All authors designed the study, developed the methodology, and discussed the results. Irene Johannsen, Jennifer Hengst and Alexander Goll executed and analyzed the experiments and wrote the paper while Britta Höllermann and Bernd Diekkrüger supervised the work.

Conflicts of Interest: The authors declare no conflict of interest. The founding sponsors had no role in the design of the study; in the collection, analyses, or interpretation of data; in the writing of the manuscript, and in the decision to publish the results.

\section{References}

1. Droogers, P.; Immerzeel, W.W.; Terink, W.; Hoogeveen, J.; Bierkens, M.F.P.; van Beek, L.P.H.; Debele, B. Water Resources Trends in Middle East and North Africa Towards 2050. Hydrol. Earth Syst. Sci. 2012, 16, 3101-3114. [CrossRef]

2. Le Page, M.; Berjamy, B.; Fakir, Y.; Bourgin, F.; Jarlan, L.; Abourida, A.; Benrhanem, M.; Jacob, G.; Huber, M.; Sghrer, F; et al. An Integrated DSS for Groundwater Management Based on Remote Sensing. The Case of a Semi-arid Aquifer in Morocco. Water Resour. Manag. 2013, 26, 3209-3230. [CrossRef] 
3. Africa Progress Report. Grain, Fish, Money. Financing Africa's Green and Blue Revolutions; Senegal, 2014. Available online: http://app-cdn.acwupload.co.uk/wp-content/uploads/2014/05/APP_APR2014_24june. pdf (accessed on 14 March 2016).

4. Busche, H.G.K. Hydrology of the Drâa Basin. In Impetus Atlas Morocco: Research Results 2000-2007, 3rd ed.; Schulz, O., Judex, M., Eds.; Department of Geography, University of Bonn: Bonn, Germany, 2008; pp. 43-44. Available online: http://www.impetus.uni-koeln.de/en/impetus-atlas/impetus-atlasmorocco.html (accessed on 14 March 2016).

5. Messouli, M.; Ben Salem, A.; Ghallabi, B.; Yacoubi-Khebiza, M.; Ait Boughrous, A.; El Alami El Filali, A.; Rochdane, S.; Ezzahra Hammadi, F. Ecohydrology and Groundwater Resources Management under Global Change: A Pilot Study in the Pre-Saharan Basins of Southern Morocco. Options Méditer. 2009, 88, 255d-264d. [CrossRef]

6. Karmaoui, A.; Messouli, M.; Ifaadassan, I.; Khebiza, M.Y. A Multidisciplinary Approach to Assess the Environmental Vulnerability at Local Scale in Context of Climate Change (Pilot Study in Upper Draa Valley, South Morocco). Glob. J. Technol. Optim. 2014, 6, 1-11. [CrossRef]

7. Busche, H.G.K. Modeling Hydrological Processes in a Semi-arid Mountainous Catchment at the Regional Scale. Dissertation, University of Bonn, Bonn, Germany, August 2012. Available online: http://hss.ulb.unibonn.de/2013/3173/3173.htm (accessed on 14 March 2016).

8. Ghallabi, L.B.; Messouli, M.; Yacoubi, M. Integrated Approaches to the Assessment of the Impacts of Climate and Socio-economic Change on Groundwater Resources in the Tensift Basin, Morocco. Int. J. Water Resour. Arid Environ. 2011, 1, 219-225. Available online: http://www.psipw.org/attachments/article/304/IJWRAE_ 1\%283\%29219--225.pdf (accessed on 14 March 2016).

9. Ben Salem, A.; Messouli, M.; Yacoubi-khebiza, M. Developing an Oasis-Based Water Management Tool: Ecohydrologic Approach and Weap Software for a Large Arid Catchment in Morocco. Int. J. Water Resour. Arid Environ. 2011, 1, 387-396.

10. Rochdane, S.; Reichert, B.; Messouli, M.; Babqiqi, A.; Khebiza, M.Y. Climate Change Impacts on Water Supply and Demand in Rheraya Watershed (Morocco), with Potential Adaptation Strategies. Water 2012, 4, $28-44$. [CrossRef]

11. Klose, S. Regional Hydrogeology and Groundwater Budget Modeling in the Arid Middle Drâa Catchment. Dissertation, University of Bonn, Bonn, Germany, November 2012. Available online: http:/ /hss.ulb.unibonn.de/2013/3330/3330.htm (accessed on 14 March 2016).

12. Fink, A.; Reichert, B.; Christoph, M. West Africa An Integrated Approach to the Efficient Management of Scarce Water Resources in West Africa. In Impetus Atlas Morocco: Research Results 2000-2007, 3rd ed.; Schulz, O., Judex, M., Eds.; University of Bonn: Bonn, Germany, 2008; pp. 2-4. Available online: http: //www.impetus.uni-koeln.de/en/impetus-atlas/impetus-atlas-morocco.html (accessed on 14 March 2016).

13. Schulz, O. Snow Cover Variability in the High Atlas Mountains. In Impetus Atlas Morocco: Research Results 2000-2007, 3rd ed.; Schulz, O., Judex, M., Eds.; University of Bonn: Bonn, Germany, 2008; pp. 22-23. Available online: http://www.impetus.uni-koeln.de/en/impetus-atlas/impetus-atlas-morocco. html (accessed on 14 March 2016).

14. Hellegers, P.; Immerzeel, W.; Droogers, P. Economic Concepts to Address Future Water Supply-Demand Imbalances in Iran, Morocco and Saudi Arabia. J. Hydrol. 2013, 502, 62-67. [CrossRef]

15. Hamlat, A.; Errih, M.; Guidoum, A. Simulation of Water Resources Management Scenarios in Western Algeria Watersheds Using WEAP Model. Arab. J. Geosci. 2013, 6, 2225-2236. [CrossRef]

16. Zaoui, S.O.; Snani, S.; Djebbar, Y. Management of Water Resources at Souk-Ahras Region (Algeria). In Proceedings of the 14th International Water Technology Conference, IWTC 14, Cairo, Egypt, 21-23 March 2010; pp. 599-608. Available online: http://www.iwtc.info/2010_pdf/09--05.pdf (accessed on 12 March 2016).

17. Yates, D.N.; Sieber, J.; Purkey, D.R.; Huber-Lee, A. WEAP21-A Demand-, Priority-, and Preference-Driven Water Planning Model. Part 1: Model Characteristics. Water Int. 2005, 30, 487-500. [CrossRef]

18. Joyce, B.; Vicuña, S.; Dale, L.; Dracup, J.; Hanemann, M.; Purkey, D.; Yates, D. Climate Change Impacts on Water for Agriculture in California: A Case Study in the Sacramento Valley; California Climate Change Center: Sacramento, CA, USA, 2006. 
19. Purkey, D.; Joyce, B.; Vicuna, S.; Hanemann, M.; Dale, L.; Yates, D.; Dracup, J. Robust Analysis of Future Climate Change Impacts on Water for Agriculture and Other Sectors: A Case Study in the Sacramento Valley. Clim. Chang. 2008, 87, 109-122. [CrossRef]

20. Höllermann, B.; Giertz, S.; Diekkrüger, B. Benin 2025-Balancing Future Water Availability and Demand Using the WEAP ‘Water Evaluation and Planning' System. Water Resour. Manag. 2010, 24, 3591-3613. [CrossRef]

21. Hoff, H.; Bonzi, C.; Joyce, B.; Tielbörger, K. A Water Resources Planning Tool for the Jordan River Basin. Water 2011, 3, 718-736. [CrossRef]

22. Speth, P., Christoph, M., Diekkrüger, B., Eds.; Impacts of Global Change on the Hydrological Cycle in West and Northwest Africa; Springer Verlag: Heidelberg, Germany, 2010.

23. Schulz, O., Judex, M., Eds.; IMPETUS Atlas Marocco: Research Results 2000-2007, 3rd ed.; Department of Geography, University of Bonn: Bonn, Germany, 2008.

24. Klose, A. Soil Characteristics and Soil Erosion by Water in a Semi-arid Catchment (Wadi Drâa, South Morocco) under the Pressure of Global Change. Dissertation, University of Bonn, Bonn, Germany, August 2009. Available online: http://hss.ulb.uni-bonn.de/2009/1959/1959.htm (accessed on 14 December 2016).

25. Diekkrüger, B.; Busche, H.; Giertz, S.; Steup, G. Hydrology. In Impacts of Global Change on the Hydrological Cycle in West and Northwest Africa; Speth, P., Christoph, M., Diekkrüger, B., Eds.; Springer Verlag: Heidelberg, Germany, 2010; pp. 60-64.

26. Heidecke, C. Economic Analysis of Water Use and Management in the Middle Drâa Valley in Morocco. Ph.D. Thesis, University of Bonn, Bonn, Germany, September 2009. Available online: http:/ /hss.ulb.unibonn.de/2010/2022/2022.pdf (accessed 14 December 2016).

27. Platt, S. Current Development of the Population in the Provinces of Ouarzazate and Zagora. In Impetus Atlas Morocco: Research Results 2000-2007, 3rd ed.; Schulz, O., Judex, M., Eds.; University of Bonn: Bonn, Germany, 2008; pp. 59-60. Available online: http://www.impetus.uni-koeln.de/en/impetus-atlas/impetusatlas-morocco.html (accessed on 14 March 2016).

28. Heidecke, C.; Schmidt, T. Agricultural Land Use. In Impetus Atlas Morocco: Research Results 2000-2007, 3rd ed.; Schulz, O., Judex, M., Eds.; University of Bonn: Bonn, Germany, 2008; pp. 67-68.

29. Mehta, V.K.; Haden, V.R.; Joyce, B.A.; Purkey, D.R.; Jackson, L.E. Irrigation Demand and Supply, Given Projections of Climate and Land-use Change, in Yolo County, California. Agric. Water Manag. 2013, 117, 70-82. [CrossRef]

30. FAO. ETc—Single Crop Coefficient (Kc). Available online: http://www.fao.org/docrep/x0490e/x0490e0b. htm (accessed on 25 September 2015).

31. Reichert, B.; Jaeger, A. Socio-economic Scenarios. In Impacts of Global Change on the Hydrological Cycle in West and Northwest Africa; Speth, P., Christoph, M., Diekkrüger, B., Eds.; Springer Verlag: Heidelberg, Germany, 2010; pp. 426-441.

32. Rössler, M.; Kirscht, H.; Rademacher, C.; Platt, S.; Kemmerling, B.; Linstädter, A. Migration and Resource Management in the Drâa Valley, Southern Morocco. In Impacts of Global Change on the Hydrological Cycle in West and Northwest Africa; Speth, P., Christoph, M., Diekkrüger, B., Eds.; Springer Verlag: Heidelberg, Germany, 2010; pp. 584-597.

33. Mekonnen, M.M.; Hoekstra, A.Y. A Global Assessment of the Water Footprint of Farm Animal Products. Ecosystems 2012, 15, 401-415. [CrossRef]

34. King, J.M. Livestock Water Needs in Pastoral Africa in Relation to Climate and Forage; International Livestock Centre for Africa: Addis Ababa, Ethiopia, 1983.

35. Descheemaeker, K.; Amede, T.; Haileslassie, A. Improving Water Productivity in Mixed Crop-Livestock Farming Systems of Sub-Saharan Africa. Agric. Water Manag. 2010, 97, 579-586. [CrossRef]

36. Klose, A.; Busche, H.; Klose, S.; Schulz, O.; Diekkrüger, B.; Reichert, B.; Winiger, M. Hydrological Processes and Soil Degradation in Southern Morocco. In Impacts of Global Change on the Hydrological Cycle in West and Northwest Africa; Speth, P., Christoph, M., Diekkrüger, B., Eds.; Springer Verlag: Heidelberg, Germany, 2010; pp. 198-253.

37. Heidecke, C.; Kuhn, A.; Liebelt, C. Hydro-economic Processes and Institutions in Southern Morocco. In Impacts of Global Change on the Hydrological Cycle in West and Northwest Africa; Speth, P., Christoph, M., Diekkrüger, B., Eds.; Springer Verlag: Heidelberg, Germany, 2010; pp. 329-341. 
38. Tsur, Y. The Stabilization Role of Groundwater When Surface Water Supplies are Uncertain: The Implications for Groundwater Development. Water Resour. Res. 1990, 26, 811-818. [CrossRef]

39. Sieber, J.; Purkey, D. WEAP Water Evaluation and Planning System: User Guide; Stockholm Environment Institute: Somerville, MA, USA, 2008; Available online: http://www.weap21.org/downloads/WEAP_User_ Guide.pdf (accessed on 14 March 2016).

40. Storm, H. Willigness to Pay for Irrigation Water in the Drâa Valley in Morocco-An Application of the Contingent Valuation Method and the MIVAD Model. Unpublished Diploma Thesis, University of Bonn, Bonn, Germany, 2009.

41. Askri, B.; Ahmed, A.T.; Abichou, T.; Bouhlila, R. Effects of Shallow Water Table, Salinity and Frequency of Irrigation Water on the Date Palm Water Use. J. Hydrol. 2014, 513, 81-90. [CrossRef]

42. IPCC. Climate Change 2013: The Physical Science Basis; Intergovernmental Panel on Climate Change: New York, NY, USA, 2013.

(c) 2016 by the authors; licensee MDPI, Basel, Switzerland. This article is an open access article distributed under the terms and conditions of the Creative Commons Attribution (CC-BY) license (http:/ / creativecommons.org/licenses/by/4.0/). 